\title{
LIST OF ILLUSTRATIONS
}

The Origin of Tragedy: Adam and Eve Enter the World of

Suffering and Death . . . . . . . . . . . Frontispiece

From Boccace des Nobles Malheureux (Laurent de Premier-

fait's translation of Boccaccio's De Casibus, the second of Vérard's editions), Paris [1506?], fol. i verso.

Fortune and Her Wheel . . . . . . . . . . . facing 16

From Lydgate's The Siege of Troy, MS Royal $18 \mathrm{D}$ ii (British Muscum), fol. 30 verso; ca. I 450.

Marcus Atilius Regulus Tortured by the Carthaginians . facing 32 From Laurent de Premierfait's translation of Boccaccio's De Casibus, MS Royal I 4 E v (British Museum), fol. 239 recto; late fifteenth century.

The Fortunes of Portia, Wife of Brutus. She Dies by Swallowing Live Coals . . . . . . . . . . . . . . . . 89 From Boccaccio's De Mulieribus Claris, Ulm, 1473, fol. Ixxxiiii verso.

Pompey Beheaded . . . . . . . . . . . . . facing 96 From Laurent de Premierfait's translation of Boccaccio's De Casibus, MS Royal 14 E v (British Museum), fol. 318 verso; late fifteenth century.

The Deaths of Antony and Cleopatra . . . . . . . facing II2 From Laurent de Premierfait's translation of Boccaccio's De Casibus, MS Royal 4 E v (British Museum), fol. 339 recto; late fifteenth century.

The Slaying of Troilus by Achilles . . . . . . . . facing 144 From Lydgate's The Siege of Troy, MS Royal $18 \mathrm{D}$ ii (British Museum), fol. I10 verso; ca.1450.

Oedipus Blinded by Himself . . . . . . . . . . facing 160 From Lydgate's Fall of Princes, MS Harley 1766 (British Museum), fol. 48 recto; ca. 1450 .

The Death of Lucrece . . . . . . . . . . . . facing 208

From Laurent de Premierfait's translation of Boccaccio's De Casibus, MS Royal ${ }_{1}$ E v (British Museum), fol. 121 verso; late fifteenth century. 


\section{LIST OF ILLUSTRATIONS-Continued}

The Deaths of Virginia and Appius . . . . . . . facing 224

From Laurent de Premierfait's translation of Boccaccio's De

Casibus, MS Additional 35321 (British Museum), fol. 89

verso; late fifteenth century.

The Revenge of Orestes . . . . . . . . . . . . . 263

From Boccaccio's De Mulieribus Claris, Ulm, 1473, fol. xxxv verso.

An Elizabethan Dance of Death . . . . . . . . . . . 292

From The Daunce and Song of Death [1569?], a broadside

(British Museum, Huth 50 [32]).

The Murder of Arden of Feversham . . . . . . . . . 317

From the Complaint and Lamentation of Mistresse Arden,

a ballad (British Museum, Rox. III, Pt. I, 156).

The Murder of Horatio in The Spanish Tragedie . . . . . 393

From the edition of 1633 .

The Revenge of Titus Andronicus . . . . . . . . . . 397

From The Lamentable and Tragical History of Titus An-

dronicus, a ballad (British Museum, Huth 50 [69]). 